CHAPTER 6

\title{
Meteora within the systems of monasticism, heritage protection and tourism operation
}

\begin{abstract}
Monasticism
The relationship between the State, the Church and the Monasteries in Greece may be summarised as follows (Troianos and Poulis 2002, 60-68, 79-81 and 109-119; Venizelos 2000, 55-61, 76-84 and 91-93; on the side of the State: Stathopoulos 2000, 59-70; on the side of the Church: Ramiotis 1997, 80 and 89-92; on the side of the Monasteries: Apostolakis 2002b, 9-12 and 17-22; Apostolakis 2003, 11-18 and 23-32).

Within the framework of the freedom of religious expression and worship and of the respect to all religious groups as fundamental human rights within a Western democratic state (Greek Government 1975, article 13), Orthodox Christianity is recognised as the predominant religion in Greece. The Church of Greece still retains close links with the State and holding a primary position in Greek society (Greek Government 1975, article 3).

The Church of Greece is recognised as a 'legal entity governed by public law' [nomiko prosopo dimosiou dikaiou] within the State in the context of 'rule of law' [kratos dikaiou] model [it is an entity that, though legally distinct from the State, performs state-like functions and is empowered with competence to control its own administrative and operational affairs quasi a public body]. On this basis, the State grants the Church control of its own operational issues, in strict compliance with the Constitution and the laws of the State (Greek Government 1977). The relationship between the State and the Church in Greece is in everyday practice characterised by the efforts of the State, on the one hand, to define and regulate the operation of the Church, and by the attempts of the Church, on the other, to resist the pressure from the State (see Koliopoulos and Veremis 2002, 140-151). In the context of State-Church relationship, Greek people are at the same time citizens of the State and congregation of the Church.

The Church is governed by the Holy Synod of the Hierarchy, which consists of the Bishops of the Greek territory with the Archbishop of Athens as its President. The Church is operating in a decentralised way. Each Bishopric has a considerable degree of independence from the central Church in dealing with the issues of the operation and management of its own diocese and congregation.

Monasteries are recognised as 'legal entities governed by public law' within the Greek state (Greek Government 1977). Monasteries are, in terms of administration, dependent upon the
\end{abstract}


local Bishopric. The supervision of the local Bishopric over the Monasteries officially covers spiritual and liturgical issues (i.e. so that the Monasteries comply with the rules of the Orthodox Church) and not issues of their operation and management, which remain the responsibility of the individual Monasteries. Monasteries are also obliged to give part of their income to the local Bishopric. In practice, however, a local Bishopric's collaboration with, and influence on, the Monasteries may extend to a variety of issues other than strictly spiritual ones (Kostopoulos 2003, 267-273).

The relationship between the State, the Church and the Monasteries with regard to the site of Meteora presents further complexities (Apostolakis 2008). Initially there was a single Bishopric, but in the period 1967-1974 it was divided into two Bishoprics: one of Trikala and one of Meteora and Stagoi [Kalampaka]. Meteora Monasteries now belong in the latter. As a result of this division, the two Bishoprics are not on very good terms with each other, often with implications for the local community and for Meteora Monasteries.

Another complexity of the site of Meteora is the operation of six separate Monasteries, with different spiritual and ideological links and with different views with regard to the operation and management of the complex. These differences affect the Monasteries' relationship with the local Bishopric, the local community, the local and national government bodies.

\section{Heritage protection}

The system of heritage protection in Greece is controlled by a strict legislative framework: the ownership of heritage within the territory of Greece that is recognised as a national one, and the responsibility for its protection, are in the hands of the State (Greek Government 2008, article 24). The system of heritage protection (defined by Greek Government 1932 and Greek Government 2002) is particularly concerned about 'the safeguarding of [the monuments'] material substance and their authenticity' in an attempt to 'safeguard the historic memory for the sake of the present and the future generations' (Greek Government 2002, articles 40 and 1) and could be generally characterised by an emphasis on the preservation of the tangible/material - rather than the intangible - elements of monuments (see Kotsakis 1991, Poulios 2010 c; Poulios forthcoming; Poulios 2012a; Poulios 2012b; Poulios and Touloupa forthcoming). The responsibility for protection lies with the Ministry of Culture ${ }^{1}$; even in those cases where other government agencies (such as the Ministry of the Environment, Spatial Planning and Public Works) are also involved, the Ministry of Culture retains final responsibility. Protection is centrally administered: the central divisions of the Ministry set the policy, while the local divisions / the so-called 'Ephorates' deliver this policy at the local level (Ministry of Culture 2003; Greek Government 2002, articles 49-50; Doris 1985, 359-408; 416-446; Eugenidou 1993, 6-10; see also Pantos 1993; Papachristodoulou 2002). The protection of those sites that are inscribed on the UNESCO World Heritage List is generally the same as that of the other national designated heritage sites; the only difference is the further increased responsibility of the central Ministry, with very little involvement of the local Ephorates (Greek Government 2002, article 50).

The underlying philosophy of national heritage protection in Greece is based on Western European Classical ideals and is characterised by a strong attachment to its Classical past, as a

${ }^{1}$ The Ministry of Culture has changed form over time, on the basis of its position within the state structure and its relation to the other ministries eg. it has been for many years a Ministry of Culture only, in 2009 it incorporated Tourism and became the Ministry of Culture and Tourism, while in 2013 it became the Ministry of Culture and Sports. In the present study it is cited as 'Ministry of Culture'. 
result of a variety of factors before, during, and after the Greek revolution against the Ottoman occupation and the formation of the Greek state (1821-1832) until present day (Yalouri 2001, 187-196; Hamilakis 2000, 69-71; Hamilakis and Yalouri 1999, 116-127; Hamilakis and Yalouri 1996, 118-127; Lowenthal 1988). This attachment to the Classical past has developed at the expense of any other (than Classical) past and particularly of the Byzantine past (Yalouri 1993, 24-35). Indicative examples to this end: During the early history of the Greek state the word 'antiquities' meant in the terms of the period exclusively monuments of the Classical Greek past, and consequently, the establishment of national heritage regulations in 1833 referred exclusively to the protection of Classical antiquities (Kotsakis 1991, 65); it was not until 1899 that provisions were made for the protection of the Byzantine antiquities as well (Zias 1995, 84-86; Zias 1993, 17-18). Also, until 2002 it was only (Byzantine) sites dating before 1453 that were automatically recognised and protected as national heritage, while those (post-Byzantine) sites after 1453 required a specific listing (Greek Government 2002, article 6 replacing Greek Government 1932).

Yet, even after the recognition of Byzantine sites as 'heritage', the State's emphasis on the Classical past has substantially affected the overall way Byzantine sites were, and are still, approached and protected: First, Byzantine religious sites are looked upon from a Classical perspective, with considerable emphasis on their artistic and art-historical significance and on the need for the preservation of their fabric, while their continuing ecclesiastical and liturgical use is largely ignored (Zias 1995, 83-84). Therefore, it appears that Byzantine religious heritage was simply added to an already well-established and strict set of regulations modelled upon Western European Classical principles; and is not treated as a special category of heritage under a special set of heritage regulations (see Poulios 2010c; Poulios forthcoming).

Second, the State / the Ministry of Culture has the exclusive responsibility and power over the protection of the sites, while Church authorities, such as the Bishoprics and the monastic communities, are not (officially) included in the protection of the sites (Zias 1995, 83-84). In practice, however, the State / the Ministry of Culture has to take into account and collaborate with the monastic communities given the latter's officially recognised ownership of the sites (see above; Greek Government 2002, article 73; see Zias 1993, 18). This means that the sites are under the responsibility of two different managing authorities: as heritage sites they are under the responsibility of the Greek state, while as monastic sites they are under the responsibility of their monastic communities (see Poulios 2010c; Lavvas et al. 1997). The most effective way for the State / the Ministry of Culture to control the monastic communities is through the provision for the funding for restoration of the monasteries, imposing two requirements for the monastic communities to qualify for funding: first, to respect the fabric of the monasteries, which means that the restoration works must be authorised and supervised by the Ministry of Culture, and, second, to have the monasteries open to the visitors (public access) (Greek Government 2002, article 11). This means that practically the control by the Ministry of Culture depends on the relative financial power of the individual monastic communities and on their attitude towards tourism.

Meteora was designated at a national level initially through the inscription of individual monuments: the Varlaam, the Great Meteoron, the St Stephen and the Holy Trinity monasteries were inscribed in 1921 (Greek Government 1921), while the Roussanou, the St Nikolaos Anapafsas, the Coming of Christ, the Hagia and the Ipsilotera monasteries were inscribed in 1962 (Ministry of Culture 1962). In 1967 Meteora was recognised as a single heritage site with unified boundaries including the village of Kastraki and part of the town of Kalampaka (Ministry of Culture 1967), while the boundaries of the heritage site were re-defined in 2005 (Ministry of Culture 2005). Meteora was designated a World Heritage Site in 1988, recognised as a cultural and natural ('mixed') 'property' of 'outstanding universal value' on the basis of cultural criteria i, ii, iv, $v$ and natural criterion iii (UNESCO 1988; ICOMOS 1987a; IUCN 1988). Buffer zones for the protection 
of the site were defined in 1995 and 1996 (Ministry of Culture 1995; Ministry of Culture 1996), and were re-defined in 2002 (Ministry of Culture 2002; see also below): buffer Zone A (around the Meteora monasteries) strictly prohibits the erection of any buildings in it, while buffer Zone B (around the Meteora rocks) sets conditions on the construction of buildings in Kastraki and Kalampaka settlements (see above, figure 8).

The responsibility for the protection of the site of Meteora, given its World Heritage status, lies primarily in the central Ministry of Culture and, at a clearly secondary level, in the $19^{\text {th }}$ Ephorate of Byzantine Antiquities (based on the city of Trikala, Prefecture of Trikala). Given the significance of Meteora also as a natural heritage site, the Ministry for the Environment, Spatial Planning and Public Works is also involved in the management of the site, but the final responsibility remains in the Ministry of Culture.

Despite the general policy of the Greek government bodies not to provide any special legal framework of protection for its religious heritage (see above), Meteora was actually given a special legal status. It was recognised in 1995 as a holy site, protected against any commercial activity that would do harm to its holy character (Greek Government 1995: see below), with the boundaries of the holy site being defined in 1999 (Ministry of Culture and Ministry of Environment, Spatial Planning and Public Works 1999).

\section{Tourism operation}

Tourism is one of the current pillars of the economy of Greece (see Patsouratis 2002, 1-12; Research Institute for Tourism 2004, 47-52).

Tourism is centrally administered, with responsibilities increasingly allowed to a local level: the central divisions of the Ministry of Tourism in collaboration with the Hellenic Tourism Organisation [a Public Entity supervised by the Ministry of Tourism that is responsible for the promotion of Greek tourism] set the policy, while the local divisions deliver this policy at the local level. These government bodies collaborate with various independent tourist agencies for the setting and the delivery of the policy (Varvaressos 1999, 160-166).

The policy of the Greek state may be summarised as follows: Within the international market, which is dominated by tour operators and is operating through the selling of holiday packages for mass tourism on an 'image and price' basis, Greece is mainly promoted on the basis of the 'Sea and Sun' model for the summer period. The Greek state positions Greece within the international market in two ways: First, within the 'Sea and Sun' model: by differentiating Greece from its competitors (that are also promoted on the basis of the 'Sea and Sun' model) through the 'Sea, Sun and Culture' model. Hence, from these three elements 'culture' stands out as the quintessential aspect of the new tourism profile of Greece, and as the competitive advantage of Greece (Hellenic Tourism Organisation 2001, 7 and 12-18; Chatzidakis 2004, 7; see also Patsouratis 2002, 205 and 214-215; Tsartas et al. 2010). In this new tourism profile, 'culture' is associated with a wide range of aspects of the contemporary Greek style of life such as hospitality, a pleasant and relaxing style of life, and picturesque scenery (Hellenic Tourism Organisation 2001, 17; Chatzidakis 2004, 1-2 and 7-8). Still, a key element of this 'culture' remains cultural heritage - with an emphasis on the ancient Classical heritage, as the one more easily associated with Greece internationally due to the continuing Classical interest of the Western world (see above) (Chatzidakis 1993, 2-3; see also Touloupa 2010). Second, outside the 'Sea and Sun' model: by developing smaller, alternative tourism trends, outside the mainstream mass tourism trends and beyond the summer period. The aim is to attract segments in the existing market that cannot be satisfied by the current mass tourist trends, and potentially develop these segments and create new markets (Hellenic Tourism Organisation 2003b, Phase B, 33-35; Hellenic Tourism Organisation 2001, 11 and 14; Patsouratis 


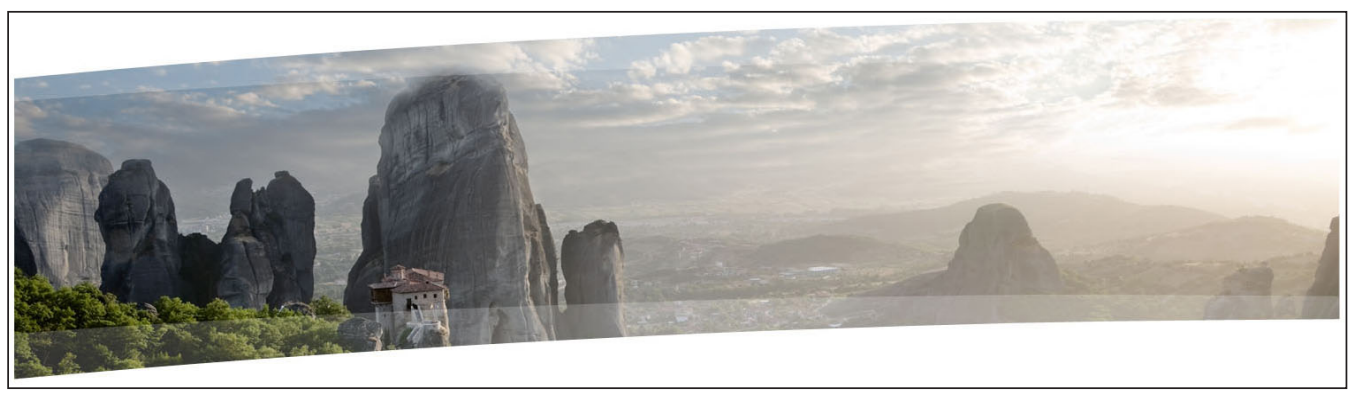

Figure 9: Tourism campaign of Meteora targeting the foreign market (source: Hellenic Tourism Organisation).

2002, 212-214; Chatzidakis 2004, 7-8; Chatzidakis 1993, 4-7; Varvaressos 1999, 33-35). Such alternative forms of tourism are cultural tourism (associated mainly with monuments-sites, museums and contemporary culture), rural tourism, and religious tourism, which is mainly aimed at the Orthodox, mainly Eastern European, markets (on religious tourism, see: Hellenic Tourism Organisation 2000; Hellenic Tourism Organisation 2003a; on religious tourism based on monasteries in use, see: Konsola 1996, 269-270; Kazazaki 1996, 325-328; Kazazaki 1999).

The Greek state also promotes the development of domestic tourism (i.e. based on the Greek visitors), outside the 'Sea and Sun' model and beyond the summer period (during which Greeks usually seek beach destinations) (Patsouratis 2002, 23-26). Among the most significant types of domestic tourism is religious tourism, with the participation of the Church authorities and the monastic communities.

Meteora is one of the most popular tourist destinations in Greece.

Meteora fits within the policy of the Greek state in the following ways. Within the international market: First, within the 'Sea, Sun and Culture' model, Meteora provides an excellent example of a site that demonstrates that Greece is much more than 'Sea and Sun' and, furthermore, much more than ancient Classical culture, thus further expanding the tourism profile of Greece (figure 9) (pers. comm. Ministry of Tourism; Hellenic Tourism Organisation 2003b, Phase B, 97). Second, outside the 'Sea, Sun and Culture' model, the region of Meteora offers a great variety of alternative forms of tourism, such as cultural tourism, rural tourism, religious tourism, and rock-climbing (Hellenic Tourism Organisation 2003, Phase B, 34-35; Charalambeas 2005, 206-210 and 255-256; Xydias and Totsikas and Braoudakis 1994, 10/17-26; 10/29-32; Chormova 1997, 285; Livanidis 1988, 2; Ministry of Coordination and Development 1980, 19).

Within the domestic market, Meteora is by far the most popular monastic site in Greece (Xydias and Totsikas and Braoudakis 1994, 10/20). The popularity of Meteora as a tourist destination is also eased by the fact that Meteora is also open to women, is much easier to access by a wellorganised transportation system, and there are no special entry procedures or restrictions in the number of the visitors (unlike for instance Mount Athos).

The operation of Meteora may be seen from a tourist point of view as follows. First, within the 'Sea and Sun (and Culture)' model (within the international market): Meteora operates as a transitory destination added to other, primary destinations and routes (such as sea resorts, and on the way from Athens to Thessaloniki) mostly during the summer period (Xydias and Totsikas and Braoudakis 1994, 10/18-19). The visitors spend approximately two to three hours visiting a couple of monasteries, make a brief stop at shops and restaurants, and move on to their final destination. The most visited monasteries are those with more open space, museums and shops (such as the Great Meteoron and the Varlaam monasteries) or those with the easiest access from the road (the St Stephen monastery). The most preferred restaurants and shops are those located 
on the roads of access to the site. The majority of the visitors do not stay in the nearby town of Kalampaka and the village of Kastraki (Xydias and Totsikas and Braoudakis 1994, 10/18-19; pers. comm. KENAKAP; Alexiadis 1998). Second, outside the 'Sea, Sun and Culture' model (within the international market, through the alternative types of tourism, and also within the domestic market): Meteora is established as a primary tourist destination at a more extended period throughout the year (Xydias and Totsikas and Braoudakis 1994, 10/19; Hellenic Tourism Organisation 2003b, Phase B, 97-98). The visitors stay in Kastraki and Kalampaka. Rock-climbers, for example, stay in the area for approximately seven days (Liolios 2006, 6).

In this context, the impact of the development of tourism at Meteora is as follows. The benefits are most significant for the Greek state through the contribution of tourism in the overall development of the country. The benefits are rather limited for the local community, with the exception of a few restaurants, souvenir shops, and hotels (see above). The benefits for the Meteora monastic communities, as the ones who control the access to the monasteries, are significant. Therefore, the key players in the tourism industry are the tour operators (international level), the Greek state (national level) and the Meteora monastic communities (local level), while the other groups of people, such as the local agents and the local community, try to benefit through their relationship with these key players.

\section{Conclusion}

The interdependence of monasticism, heritage protection and tourism oprration may be summarised as follows: Heritage protection, in principle, is in conflicting terms with the monastic sites' continuing ecclesiastical and liturgical meaning and function, and is dependent upon the monastic communities' legally recognised ownership of their monasteries. Heritage protection, in practice, considers public access a basic requirement for the provision for the funding for restoration of the monasteries, and depends on the monastic communities' attitude towards tourism and also on their relative financial power.

Meteora is a most popular tourist attraction. The monastic communities of the site, as those who control the public access to the site, play a key role in tourism industry and derive considerable power from this role, also in financial terms. The increased public access to the site, as well as the increased financial power of the monastic communities, hinders the cooperation between the State / the Ministry of Culture and the monastic communities, posing several complexities to heritage protection. 